\title{
Articulating Landscapes in Central Greece
}

Archaeology in essence then is the discipline with the theory and practice for the recovery of unobservable hominid behaviour patterns from indirect traces in bad samples.

-DAVid Clarke, "ARCHAeOlogy: the loss of iNNOCENCE"

Archaeologists necessarily work with bad data derived from a variety of inconsistent sources. Moreover, these data are not always well suited to answering the social questions of greatest interest to our discipline. A certain amount of model building is therefore necessary to fill gaps and make connections between what we can know-the hard facts of archaeological materials-and what we can infer based on these facts. This chapter presents the baseline evidence and the models drawn on in the analysis of landscape, interaction, and complexity that forms the core of this book - that is, the archaeological remains of human activity, the question of how they are distributed across the Greek landscape, and the methods used to articulate relationships between places in geographical space. I begin with some overall characterization of the archaeological dataset compiled and parsed from a number of different types of fieldwork, reports, and publications. I next provide some contextual description of the geography and history of research for each of the regions under study. Finally, I outline the analytical framework of articulating relations between communities and within landscapes and regions-spatial approaches to modeling connectivity and territory.

\section{THE BASELINE EVIDENCE: SITES, COMMUNITIES, AND REGIONAL DATASETS}

The dataset that forms the core of this analysis is comprised of about 400 archaeological sites, drawn from various types of archaeological survey and excavation data (map 3; see also appendix for a complete list and locations of all sites used in this study). These sites were cataloged in a database that recorded precise spatial 


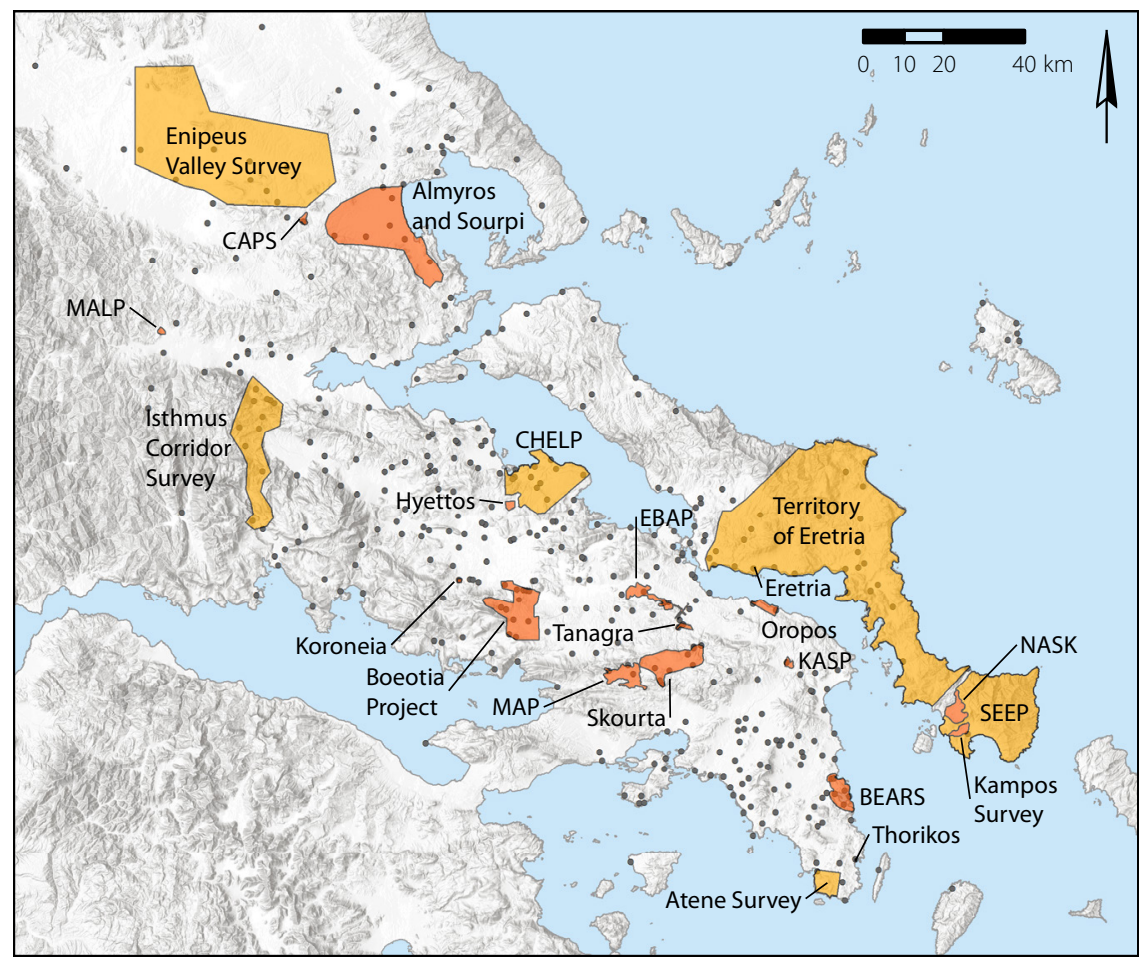

MAP 3. Archaeological surveys conducted in central Greece, with the location of archaeological sites used in the present study in the background (darker shading = intensive survey; lighter shading = extensive survey).

locations, type of site (artifact scatter, settlement, cemetery), fieldwork history, bibliography, and physical description, along with information concerning the ceramic chronology, periods represented, a site scale/hierarchy score for each period, the periods in which the site represents an independent community (a place of dwelling for a coherent social group, as opposed to a material findspot representing any other type of activity), and number of imports per period.

These sites were identified from a number of different data sources (table 3), and in any such study a certain amount of "source criticism" is necessary in order to evaluate and make compatible data collected in various different ways and for different purposes (see, e.g., Alcock 1993, 33-37; Pullen 2003; Alcock and Cherry 2004; Cunningham and Driessen 2004; Wright 2004b). As an example, Euboea illustrates the range of quality and type of archaeological data collected across a large area: Euboea is a clearly bounded island that can nonetheless be divided into multiple regions. Relevant datasets for the island include (1) gazetteers that cover all of Greece; (2) extensive surveys of the island as a whole; (3) large-scale surveys of parts of the island (for example, the territory of the polis of Eretria or the 
TABLE 3 Archaeological surveys and gazetteers for the study area

\begin{tabular}{|c|c|c|c|}
\hline Project $^{*}$ & Region & Methods & $\begin{array}{l}\text { Representative } \\
\text { publication(s) }\end{array}$ \\
\hline $\begin{array}{l}\text { Gazetteer of Aegean } \\
\text { Civilization }\end{array}$ & Greece & Gazetteer/Catalog & $\begin{array}{l}\text { Hope Simpson and } \\
\text { Dickinson } 1979\end{array}$ \\
\hline Mycenaean Greece & Greece & Gazetteer/Catalog & Hope Simpson 1981 \\
\hline $\begin{array}{l}\text { The Transition Years } \\
(1200-700 \text { BC) }\end{array}$ & Greece & Gazeteer/Catalog & Syriopoulos 1983 \\
\hline $\begin{array}{l}\text { Prehistoric Habitation } \\
\text { of Greece }\end{array}$ & Greece & Gazetteer/Catalog & Syriopoulos 1995 \\
\hline Atene Survey & Attica & $\begin{array}{l}\text { Site survey/ } \\
\text { Extensive }\end{array}$ & Lohman 1985, 1993 \\
\hline Thorikos Survey & Attica & Site survey & $\begin{array}{l}\text { Docter and Webster, } \\
\text { forthcoming }\end{array}$ \\
\hline $\begin{array}{l}\text { Bays of East Attica Regional } \\
\text { Survey (BEARS) }\end{array}$ & Attica & Intensive & Murray et al., forthcoming \\
\hline $\begin{array}{l}\text { Kotroni Archaeological } \\
\text { Survey Project (KASP) }\end{array}$ & Attica & Intensive & Andrikou et al. 2020 \\
\hline Skourta Plain Project & Attica/Boeotia & Intensive & $\begin{array}{l}\text { Munn and Munn 1989, } \\
1990\end{array}$ \\
\hline Oropos Survey Project & Attica/Boeotia & Intensive & Cosmopoulos 2001 \\
\hline Mazi Archaeological Project & Attica/Boeotia & Intensive & $\begin{array}{l}\text { Knodell, Fachard, and } \\
\text { Papangeli } 2017\end{array}$ \\
\hline $\begin{array}{l}\text { Topography and Population } \\
\text { of Ancient Boeotia }\end{array}$ & Boeotia & Gazetteer/Catalog & Fossey 1988 \\
\hline Boeotian Landscapes & Boeotia & Gazeteer/Catalog & Farinetti 2011 \\
\hline $\begin{array}{l}\text { Archaeological } \\
\text { Reconnaissance of } \\
\text { Uninvestigated Remains of } \\
\text { Agriculture (AROURA) }\end{array}$ & Boeotia & $\begin{array}{l}\text { Extensive/ } \\
\text { Intensive }\end{array}$ & Lane et al. 2016, 2020 \\
\hline $\begin{array}{l}\text { Cambridge/Bradford Boeotia } \\
\text { Expedition (Boeotia Project) }\end{array}$ & Boeotia & Intensive & $\begin{array}{l}\text { Bintliff and Snodgrass 1985; } \\
\text { Bintliff, Howard, and } \\
\text { Snodgrass 2007; Bintliff } \\
\text { et al. } 2017\end{array}$ \\
\hline $\begin{array}{l}\text { Leiden Ancient Cities of } \\
\text { Boeotia Project }\end{array}$ & Boeotia & Intensive & Bintliff et al. 2013 \\
\hline $\begin{array}{l}\text { Eastern Boeotia } \\
\text { Archaeological Project } \\
\text { (EBAP) }\end{array}$ & Boeotia & Intensive & $\begin{array}{l}\text { Burke, Burns, and Lupack } \\
\text { 2009; Aravantinos et al. } \\
2016 \text { a }\end{array}$ \\
\hline $\begin{array}{l}\text { Ancient Topography of } \\
\text { Opountian Lokris }\end{array}$ & East Lokris & Gazetteer/Catalog & Fossey 1990 \\
\hline
\end{tabular}


TABLE 3 (Continued)

\begin{tabular}{|c|c|c|c|}
\hline Project $^{*}$ & Region & Methods & $\begin{array}{l}\text { Representative } \\
\text { publication(s) }\end{array}$ \\
\hline Mycenaean East Lokris & East Lokris & Gazeteer/Catalog & Kramer-Hajos 2008 \\
\hline $\begin{array}{l}\text { Cornell Halai and East Lokris } \\
\text { Project (CHELP) }\end{array}$ & East Lokris & $\begin{array}{l}\text { Extensive/ } \\
\text { Intensive }\end{array}$ & $\begin{array}{l}\text { Coleman et al. 1992; } \\
\text { Kramer-Hajos and O’Neill } \\
2008\end{array}$ \\
\hline $\begin{array}{l}\text { Ancient Topography of } \\
\text { Eastern Phokis }\end{array}$ & Phokis & Gazetteer/Catalog & Fossey 1986 \\
\hline Folds of Parnassos & Phokis & Gazetteer/Catalog & McInerney 1999 \\
\hline $\begin{array}{l}\text { Great Isthmus Corridor } \\
\text { Survey }\end{array}$ & $\begin{array}{l}\text { Phokis/ } \\
\text { Phthiotis }\end{array}$ & Extensive & Kase et al. 1990 \\
\hline $\begin{array}{l}\text { Makrakomi Archaeological } \\
\text { Landscapes Project (MALP) }\end{array}$ & $\begin{array}{l}\text { Malis/ } \\
\text { Phthiotis }\end{array}$ & Intensive & $\begin{array}{l}\text { Papakonstantinou et al. } \\
2013\end{array}$ \\
\hline $\begin{array}{l}\text { Antiquities and public works } \\
\text { in Fthiotida, 2004-2014 }\end{array}$ & $\begin{array}{l}\text { Malis/ } \\
\text { Phthiotis }\end{array}$ & Extensive/Rescue & Papakonstantinou 2015 \\
\hline Mycenaean Thessaly & Thessaly & Gazetteer/Catalog & Feuer 1983 \\
\hline Enipeus Valley & Thessaly & Extensive & Decourt 1990 \\
\hline Almiros and Sourpi Plains & Thessaly & Intensive & $\begin{array}{l}\text { Reinders 2004; Stissi et al. } \\
2015\end{array}$ \\
\hline $\begin{array}{l}\text { Central Achaia Phthiotis } \\
\text { Survey (CAPS) }\end{array}$ & $\begin{array}{l}\text { Thessaly/ } \\
\text { Phthiotis }\end{array}$ & Intensive & Haagsma 2019 \\
\hline Euboea Survey & Euboea & $\begin{array}{l}\text { Gazetteer/ } \\
\text { Catalog/ } \\
\text { Extensive }\end{array}$ & Sackett et al. 1966 \\
\hline Territory of Eretria & Euboea & Extensive & Fachard 2012 \\
\hline Eretria Survey & Euboea & Intensive & Simon 2002 \\
\hline $\begin{array}{l}\text { Southern Euboea Exploration } \\
\text { Project (SEEP) }\end{array}$ & Euboea & Extensive & $\begin{array}{l}\text { Keller 1985; Keller and Hom } \\
\text { 2010; Cullen et al. 2013; } \\
\text { Wickens et al. } 2018\end{array}$ \\
\hline Kampos Survey & Euboea & Intensive & $\begin{array}{l}\text { Tankosic and Chidiroglou } \\
2010\end{array}$ \\
\hline $\begin{array}{l}\text { Norwegian Archaeological } \\
\text { Survey of the Karystia }\end{array}$ & Euboea & Intensive & Tankosic et al., forthcoming \\
\hline
\end{tabular}

* In addition to the projects and gazetteers listed here I have made extensive use of the following databases: the Myceanaean Atlas Project (http://helladic.info); the Aristeia project's online database of Early Iron Age and Archaic sites (http://aristeia.ha.uth.gr/); and a database of LBA and EIA sites in Greece and Crete compiled by Murray (unpublished, but now integrated in the Mycenaean Atlas Project and discussed in detail in Murray 2013, 2017).

Karystia); (4) intensive surveys of particular microregions, such as the Kampos Plain within the Karystia; (5) large-scale foreign research excavations of major sites (for example, at Eretria, Lefkandi, or Plakari); and (6) a wide range of salvage 
excavations conducted by the Greek Archaeological Service. ${ }^{1}$ Similar hodgepodges of data with a diversity of resolution, methods of collection, and level of publication can be observed for most regions in Greece. ${ }^{2}$

Taken as a whole, such a dataset is quite different from the carefully collected microregional datasets produced by modern intensive survey projects. The fact of the matter, however, is that the haphazard concatenation of evidence from travelers' accounts, extensive explorations, intensive surveys, rescue excavations, and research excavations is simply what we have for the vast majority of the archaeological landscape. If we are going to address research questions of relevance beyond the individual field project, we need to find ways to put often unwieldy bodies of evidence in dialogue with each other-and not just from large, well-excavated sites or systematic intensive surveys.

\section{Sites}

In this study I take the site as the common denominator across the archaeological landscape. While many modern surveys consider the individual artifact the basic unit of analysis, this approach is impractical if not impossible when conducting a comparative study over multiple regions, involving information from dozens of projects. Sites are defined here as findspots or groups of findspots at which a demonstrable presence from at least one of the periods in question has been identified. In combing through the datasets outlined above, each site was classified first as one of five types of archaeological assemblage: (1) artifacts (found as surface scatters or in excavations not associated with other remains); (2) isolated tombs; (3) cemeteries (more than one tomb or remains estimated to be from more than one tomb); (4) settlements (defined by the presence of architectural remains for habitation or other permanent activity); and (5) sites that combine many of the

1. For relevant gazetteers and surveys, see table 3. Synthetic studies have focused on particular periods or topics, such as prehistory (Sackett et al. 1966), medieval towers (Lock 1986, 1996), or the territory of Eretria (Fachard 2012). The longest running foreign excavations in Euboea are at Eretria, by the Swiss School of Archaeology in Greece (ESAG) (see annual reports in Antike Kunst and the 25-volume Eretria publication series) and by the British School of Archaeology in Greece (BSA) at Lefkandi (Lefkandi Vols. I-IV). A Dutch team has more recently started an excavation project at Plakari (Crielaard et al. 2015). A recent conference on the archaeology of the island as a whole has both filled gaps and revealed new ones, especially concerning the northern part of the island: see Tankosić, Mavridis, and Kosma 2017. The work of the Greek Archaeological Service is published almost exclusively in Greek in Archaiologikon Deltion, Athens Annals of Archaeology, and in various national and regional conference proceedings (e.g., Mazarakis Ainian 2006, 2009, 2012C, 2016, 2020).

2. Recent handbooks (Lemos and Kotsonas 2020; Middleton 2020) provide syntheses for several of the individual regions dealt with in this book: Athens and Attica (Alexandridou 2020; Osborne 2020); Boeotia (Aravantinos 2020; Maggidis 2020); Euboea (Lemos 2020); East Lokris and Phokis (Livieratou 2020); and Thessaly (Karouzou 2020). An Inventory of Archaic and Classical Poleis (Hansen and Nielsen 2004) is also an invaluable resource for the political geography of later periods. 
TABLE 4 Types of sites by period

\begin{tabular}{lcccccc}
\hline \multirow{2}{*}{ Type of site } & Early & Palatial & Postpalatial & Prehistoric & Protohistoric & \\
\hline Artifacts & 24 & 78 & 26 & 34 & 63 & 132 \\
Isolated tomb & 2 & 15 & 8 & 6 & 2 & 20 \\
Cemetery & 21 & 63 & 39 & 39 & 46 & 106 \\
Settlement & 26 & 51 & 30 & 25 & 25 & 62 \\
Multicomponent & 41 & 69 & 49 & 48 & 67 & 81 \\
Total Sites & 114 & 276 & 152 & 152 & 203 & $401^{*}$ \\
\hline
\end{tabular}

"Note that this number represents the sum of totals on the $\mathrm{Y}$-axis but not the $\mathrm{X}$-axis. On the $\mathrm{X}$-axis a single site may date to multiple periods, but on the $\mathrm{Y}$-axis each site is given only a single designation for the type of remains present. See the appendix for a list of sites, with type indicated and periods represented.

above components or have some other special function (such as a sanctuary or ritual site) (table 4).

There have been periodic efforts to integrate site information across all of Greece for all or parts of the period in question. For the Bronze Age, Hope Simpson and Dickinson's Gazetteer (1979) is particularly relevant, even if now quite dated (see also Hope Simpson 1981). For all of prehistory up to the Geometric period, Syriopoulos (1995) has mapped and characterized all archaeological sites in Greece, following an earlier catalogue on the "transition years" (1200-70o BCE) (Syriopoulos 1983). On central Greece in the Early Mycenaean period, Phialon (2011) is also an essential resource. Electronic databases are the more modern, accessible, and adaptable versions of gazetteers. For the Bronze Age, Consoli's Mycenaean Atlas Project is a crucial resource for sites in Greece and elsewhere in the Aegean (www.helladic.info). For the Early Iron Age, the Aristeia project has catalogued sites from all over the Greek world (Mazarakis Ainian, Alexandridou, and Charalambidou 2017; http://aristeia.ha.uth.gr). Another recent dataset relevant to this study was compiled by Murray, who mapped and tabulated site counts for all of mainland Greece and Crete (table 5; Murray 2013, 2017, 137-42). ${ }^{3}$ Across all these databases, there are some significant differences in methods of site definition, quantification, and detail of coverage, which result in a different shape of the data overall. One important aspect of all of these datasets is the number of sites that come from rescue excavations in the large urban centers of Athens, Thebes, Lamia, and Volos. While these are typically counted as individual sites, I counted them as findspots within a single larger site that encompasses several findspots (see figure 1). For example, downtown Athens contains over 160 sites in the Aristeia database, while in my reckoning it is only counted as one, albeit

3. This database was shared with me and has now been integrated into the Mycenaean Atlas Project, accessed December 4, 2020, http://www.helladic.info. See Murray 2013 for an earlier list and a tabulation of sites. 
TABLE 5 Numbers and types of sites recorded by Murray $(2017,141$, table 3.12) for the Greek mainland and Crete

\begin{tabular}{lcccc}
\hline Type of site & LH IIIB & LH IIIC & Protogeometric & Geometric \\
\hline Artifacts & 610 & 318 & 260 & 450 \\
Cemetery & 450 & 205 & 245 & 332 \\
Settlement & 306 & 132 & 95 & 166 \\
Total sites & 1366 & 655 & 600 & 948 \\
\hline
\end{tabular}

one of great significance. Whether this is the "right" approach to site definition is debatable, and one might also imagine a dataset with well over 1,00o sites for the large study area delimited here. One of these approaches is not more accurate than the other; they simply employ different methods of site definition, which result in different quantifications. The approach to site definition adopted here is meant to filter through a certain amount of noise and inflation that happens in highly populated areas that have received more attention from archaeologists (especially in the form of rescue excavations), in order to come up with a more balanced picture of settlement across the central Greek landscape. Scalar differences made apparent through extensive archaeological work in certain areas are nevertheless significant, and they are reflected in the way that a site scale or hierarchy score is ascribed to each site.

\section{Settlement Patterns and Hierarchies}

Settlement pattern analysis often includes some designation of hierarchy, or at least differentiation in scale (see, e.g., Willey 1953; Wright 1977; Bintliff 1997; Driessen 2001; Bevan and Conolly 2006; Bevan and Wilson 2013). While strict notions of hierarchy have become somewhat unfashionable, they remain useful designations in establishing a baseline pattern, especially with large datasets. It is important to recognize, however, the multiplicity of hierarchical relationships in the landscape, and to consider heterarchy, cooperation, and collective action alongside these relationships (Crumley 1995; DeMarrais and Earle 2017).

In this study of settlement patterns, all sites are classified based on scale-that is, where they fall in a relative hierarchy, which also recognizes the likely presence of heterarchical (or alternatively, simply nonhierarchical) relationships. Here, scale is determined by the type and extent of archaeological remains at a given site, with four general levels (table 6): (1) findspots of artifacts or isolated tombs that demonstrate little more than human presence dating to a particular period; (2) minor sites, which can be represented by evidence of any type, including substantial sherd scatters and limited architectural or cemetery remains; (3) major sites, which are distinguished from minor sites based on factors such as size, quantity of archaeological remains, evidence for social stratification, fortification and other major building projects, level of connectivity (as evidenced by regional or 
TABLE 6 Numbers of sites and communities occupied during each period, with settlement hierarchy indicated

\begin{tabular}{|c|c|c|c|c|c|}
\hline $\begin{array}{l}\text { Level in } \\
\text { Settlement } \\
\text { Hierarchy }\end{array}$ & $\begin{array}{l}\text { Characteristics of } \\
\text { archaeological evidence }\end{array}$ & $\begin{array}{c}\text { Palatial } \\
\text { BA }\end{array}$ & $\begin{array}{l}\text { Postpalatial } \\
\text { BA }\end{array}$ & $\begin{array}{l}\text { Prehistoric } \\
\text { IA }\end{array}$ & $\begin{array}{c}\text { Protohistoric } \\
\text { IA }\end{array}$ \\
\hline 1 & $\begin{array}{l}\text { Findspot of a few artifacts } \\
\text { or isolated tomb }\end{array}$ & $58\left(21 \%{ }^{*}\right)$ & $29(19 \%)$ & $38(25 \%)$ & 49 (24\%) \\
\hline 2 & $\begin{array}{l}\text { Limited settlement or } \\
\text { cemetery site }\end{array}$ & $157(57 \%)$ & $95(63 \%)$ & $86(57 \%)$ & $113(55 \%)$ \\
\hline 3 & $\begin{array}{l}\text { Extensive settlement and/ } \\
\text { or cemetery site, major } \\
\text { buildings, evidence for } \\
\text { social stratification, } \\
\text { regional prominence }\end{array}$ & $55(20 \%)$ & $26(17 \%)$ & $24(16 \%)$ & $35(17 \%)$ \\
\hline 4 & $\begin{array}{l}\text { Site with monumental } \\
\text { building, interregional } \\
\text { preeminence in political, } \\
\text { ritual, or economic } \\
\text { activities }\end{array}$ & $6(2 \%)$ & $3(2 \%)$ & $3(2 \%)$ & $6(3 \%)$ \\
\hline Total sites & & 276 & 152 & 152 & 203 \\
\hline $\begin{array}{c}\text { Total } \\
\text { communities } \\
\text { (\% of sites) }\end{array}$ & & $190(69 \%)$ & $114(76 \%)$ & $110(72 \%)$ & $136(67 \%)$ \\
\hline
\end{tabular}

"Percentages indicate the percentage of the total number of sites for that period.

interregional imports, and location within the wider settlement network), or reference in the documentary record; (4) exceptional sites, such as palaces, major centers, or regional sanctuaries.

These distinctions are often arbitrary, especially since many similarly sized sizes have received different levels of archaeological attention. While both Psachna in Euboea and Eleon in Boeotia appear to be major sites during the Palatial Bronze Age based on the surface record, only the latter has been confirmed as such by systematic excavation (Burke et al. 2020). Many more sites are known only through surface survey or limited excavation, though it would be a mistake to exclude them from the wider analysis. It is therefore often necessary to offer a best estimate in determining a hierarchy score, especially when dealing with sites known only from surface remains.

This type of ranking is not intended to indicate a definite political hierarchy. For example, level 3 sites should not be understood to control or dominate level 2 sites, although in some cases such a relationship may be present. Site ranking is provided rather to signal differences in scale and intensity of occupation in the landscape. More specific political hierarchies can be elucidated in other ways, depending on the organization of the political landscape for the period in question. 
Unlike some studies of settlement patterns, this one does not engage in systematic quantifications involving site size and population estimates, at least not across the dataset as a whole. This is simply because these things cannot be clearly documented or accurately modeled for the majority of the early Greek landscape, where sites have been defined and measured in a variety of ways that are rarely consistent. ${ }^{4}$ Rather, I draw comparative data from the more consistently discernable (though admittedly loosely defined) scale of the archaeological record itself, as represented by sites. I see this as a preferable alternative to "guestimates" regarding site-size averages and population data that are largely impossible to define across much of the dataset.

By focusing on archaeological sites, I document and model scalar differences in archaeological remains in relative terms, and in a way that accounts for ambiguity and diversity across the dataset as a whole. By keeping this system consistent within this study, and examining change over time, we can go beyond simple dots on a map to describe a settlement pattern that includes both palatial constructions and nondescript activity zones, represented by archaeological remains ranging from monumental fortifications to small scatters of a few pot sherds. From there we can move to questions of social organization as represented by the (often uneven) material record of individual sites and across the landscape as a whole.

\section{Communities}

I have also evaluated sites based on their relationship to other nearby sites/findspots in order to assess whether and when a site represents an independent community. Community has proven a useful framework for discussing social groups in a variety of archaeological contexts, most notably in Mesoamerica (Canuto and Yaeger 2000), the Middle East (Porter 2013), and both sides of the Mediterranean (Steidl 2020). Here I define communities as coherent social groups whose members, by virtue of proximity, have had habitual interactions with one another in a

4. The archaeological record of early Greece as a whole is particularly ill-suited to systematic estimates of site size and population, since most sites are known only through fragmentary surface remains or limited excavations. Our ability to estimate the extent of a site also varies depending on the system of site definition and measurement employed by an individual researcher or project. There also is not a standard or reliable formula in Mediterranean archaeology to translate site size or living surface into number of households or individuals living at a site. Population estimates involve even more variables and are often dependent on even more inconsistent data (see, e.g., Chamberlain 2006; Bintliff 2020, 24). Estimates based on the burial record may return different results from those based on habitation zones, and the textual record (when it exists) may suggest something different entirely. Urban and rural areas will also have different population densities, and these, too, will vary over time. This does not mean that discussions of demography are not worth having; they certainly are, and there are several good examples, based on a number of factors: site numbers, modeled site sizes, regional carrying capacity, level of urbanization, aggregated radiocarbon dates, and so on (for early Greece, see, e.g., Bintliff 1977b, 2012, 2020; Murray 2017, 211-46; Weiberg et al. 2019; Vidal-Cordasco and Nuevo-López 2021). 
way that makes them distinct from other social groups; these may or may not be part of a larger sociopolitical formation (see figure 1).

In archaeological terms, community refers to the material signature of a site where one or several kin groups were dwelling in physical proximity to one another and interacting with the surrounding landscape and other such places of dwelling. We can assume a shared identity based on habitual interactions within a particular zone of interconnected places. In this study, in the case of several findspots or sites whose relationship can be demonstrated or inferred by proximity or some other means, one is selected to be representative of the community as a whole. For example, let us consider Late Bronze Age Tanagra, a settlement with a number of cemeteries surrounding it. While there are numerous sites (a settlement site with architectural remains, some cemeteries, some isolated tombs, several clusters of artifacts), they most likely represent a single, relatively coherent community. A similar approach was used in Wright's $(2004 \mathrm{~b}, 119)$ study of the northeastern Peloponnese, which also integrated site information from multiple sources in order to avoid "double counting" settlements and their cemeteries. So, while all individual sites are mapped, only one in the group would be designated as representative of the collective community. This distinction takes an interpretative step beyond site distributions in order to make better sense of human social groups and relations between them, as interactions between communities are modeled using nearest-neighbor analyses (see further below). At the same time, connectivity models between sites signal pathways between the locations of archaeological remains (which still represent important loci of human activity). Sites and communities thus remain equally important-but qualitatively different-designations of physical archaeological remains (sites) representative of hubs of human social activity (communities).

Deciding what constitutes a community is naturally a subjective process given the unequal nature of the dataset. In the context of this study, this decision involved going through the dataset as a whole and looking at each site in context. Based on its scale, the type of remains present, and its location in relation to other sites, it was decided whether and in what periods a site represented a community. For example, Larymna is clearly a significant community in the Late Bronze Age owing to the architectural remains and the widespread artifactual finds dated to LH IIIB. The Postpalatial period, however, is represented only by a few sherds, which is enough to put it on the map as a site but probably does not justify calling it a community, by which I mean a discreet place of habitation for a coherent social group.

\section{Diachronic Patterns and Regional Trends}

Diachronic trends and patterns in the numbers and types of sites and communities are naturally telling, and some preliminary observations are worth highlighting here (see also table 4). The first is that the Mycenaean Palatial period is an anomaly 
in the history of the settlement of central Greece. With 276 sites of that period, it represents a massive expansion of material evidence from the preceding Early Mycenaean period, with 108 sites, or 154 if one also counts sites that are ambiguously reported as "Mycenaean." (The reasoning here is that LH III Palatial period pottery is often easier to distinguish, so Mycenaean pottery of uncertain date is likely to be earlier.) This latter number is generally consistent with the number of sites in the Postpalatial period (152) and in the Prehistoric Iron Age (152). A significant period of growth is observed in the Protohistoric Iron Age (203 sites), but this is still a far cry from the Mycenaean Palatial boom. Second, the numbers of sites that represent individual communities are lower in the Palatial Bronze Age and Protohistoric Iron Age than in the Postpalatial Bronze Age and Prehistoric Iron Age (see table 6). This difference is attributable to the number of sites represented only by artifacts or cemetery remains that are found in close proximity to one another, usually in the course of rescue excavations. This may also have something to do with the greater recognizability of Mycenaean Palatial and Late Geometric pottery.

The basic pattern outlined above for central Greece follows a general trend that is similar to the rest of Greece in terms of the rise and fall in site numbers, but it does so on a significantly less dramatic scale. That is to say, the percentage increases and decreases are much higher for Greece as a whole than for central Greece. In tabulations for Greece as a whole (see table 5), the number of sites is cut in half, from the Palatial to the Postpalatial Bronze Age. This is followed by a modest drop in the Early Iron Age and a roughly 50 percent increase in the Geometric period. While these variations follow the general trend seen in central Greece, the degree of change is quite different. This discrepancy indicates a need to break from global discussions of the Greek world during this transitional period. Significant variation can be detected, for example, between central Greece, the Peloponnese, Crete, and the Aegean islands. Moreover, regional patterns within central Greece also reveal major departures from the overall trends (figure 2). While Attica and Boeotia show dramatic variation over the periods in question, Euboea, Phokis, Malis, and East Lokris remain fairly steady in their site numbers; Thessaly is somewhere in between. The pattern for Greece as a whole is most closely approximated by the case of Boeotia, but this overall trend simply does not obtain when the dataset is broken down by region.

\section{THE ARCHAEOLOGICAL LANDSCAPES \\ OF CENTRAL GREECE}

Central Greece has been defined in a variety of ways. On the one hand, there is the modern administrative district of Sterea Ellada, including the subregions of Boeotia, Euboea, Phokis, Phthiotis, and Evritania. When defined geographically, it includes the regions above, as well as Attica and Aetolia-Acarnania in western Greece; in this way central Greece is set apart from the Peloponnese, the Aegean 


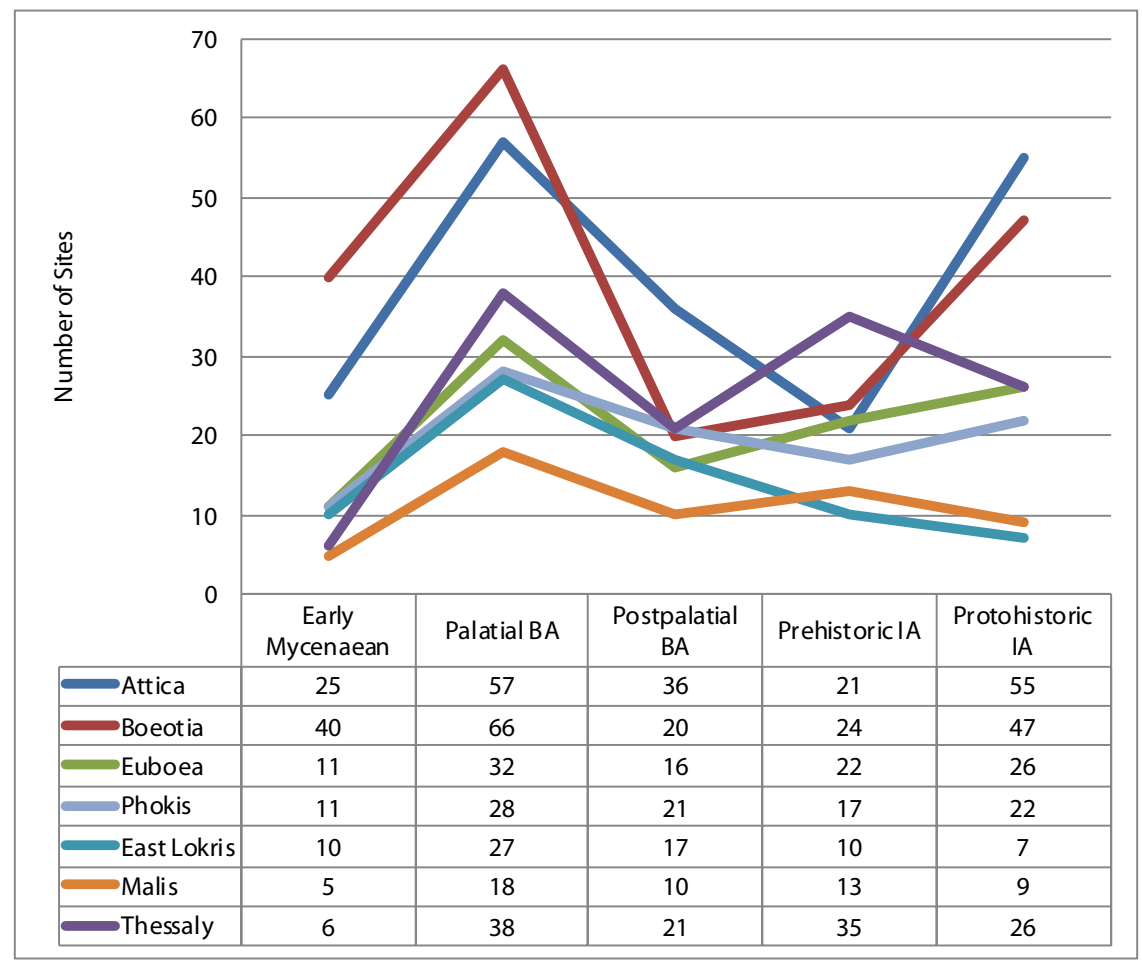

FIGURE 2. Line graph and table of number of sites by period, by region, in central Greece (see also appendix for site names, regions, and periods).

islands, and northern Greece. These zones are further connected by two key conduits that facilitate connectivity across the macroregion as a whole. On the eastern side of the study area, the Euboean Gulf provides a maritime axis through which every region in this study is connected except for Phokis (Knodell 2013, 2017). On the western side of the study area the Great Isthmus Corridor Route plays a similar role, connecting the Euboean and Corinthian Gulfs, along with southern, central, and northern Greece (Kase et al. 1991).

In the textual record, central Greece first appears in Homer's Catalog of Ships (Iliad 2.303), where Aulis is named as the mustering point for the Greek army bound for Troy. Homer proceeds to make his way roughly clockwise through the regions considered in this book (Jasnow, Evans, and Clay 2018). He starts with the towns of eastern Boeotia, then moves on to western Boeotia and Phokis, before returning to East Lokris on the coast. Shifting to Euboea, whose inhabitants are the Abantes, Homer describes the entire island as a coherent geographical unit, with settlements listed from north to south (Iliad 2.536-45). From Karystos, Homer crosses over into Attica and records the Athenian contribution, mentioning no other places in Attica except Salamis (2.546-58). Only after mentioning 
Athens does Homer move to the contingents from the Peloponnese that played the leading role in his narrative. After these he comes to Malis/Phthiotis and Thessaly (2.681-715).

The catalogue thus provides information about regional designations and the polities within them that would be maintained in similar form throughout the Classical period and, in some cases, until the present day (see also Hope Simpson and Lazenby 1970; Visser 1997; on polities of Archaic and Classical times, see Hansen and Nielsen 2004). So, while political territories changed over time, the geographical regions in which they were embedded were considered coherent landscapes - in this case Boeotia (divided into east and west), Phokis, Lokris, Euboea, and Attica, with Malis and Thessaly being somewhat apart. Given this resilience and the basis of these groupings in physical geography and relational space, it seems likely that these groupings would have obtained in earlier periods as well, at least in some form. The regions included here also correspond with the distribution of Mycenaean material culture on the mainland north of the Peloponnese and on Euboea (see map 2). In this way, the material and textual reasons for lumping these regions together also bracket the two ends of the chronological spectrum treated in this book. Following Homer, I begin with Boeotia and move roughly clockwise around the study area to summarize the geographical features, the connective routes, and (briefly) the history of research for each region.

\section{Boeotia}

The borders of Boeotia are clearly defined by Mounts Kithairon and Parnes to the south and Mount Chlomon (the southeastern end of the Kallidromon range) in the north (map 4). The area between contains a valley system with plains much larger than those found elsewhere in central Greece, with the exception of Thessaly. The principal geographical features of Boeotia are the two large, fertile, agricultural plains within and around which archaeological evidence for settlement is concentrated. These plains are dominated by the sites of Thebes and Orchomenos, although several other, independent communities flourished in various periods (Farinetti 2011).

From the west, one can enter Boeotia from the Corinthian Gulf just north of Mount Kithairon, at Livadostro Bay and the site of Kreusis. Heurtley (1925) observed remains of a road along this route, which he thought were from a Mycenaean road toward Thebes. A land route then runs east-northeast along the north edge of Kithairon, past Eutresis, to Thebes, located roughly equidistant from the Euboean and Corinthian Gulfs. From Thebes, there are two principal paths one can take east to the Euboean Gulf, both of which begin in the direction of Eleon, before splitting there to go northeast toward Aulis and east-southeast toward Tanagra and the coastal sites of Plaka Dilesi and Skala Oropou (Oropos). Another path from Thebes to the Euboean Gulf leads north, then northeast and is funneled into the gulf at the location of Anthedon. 


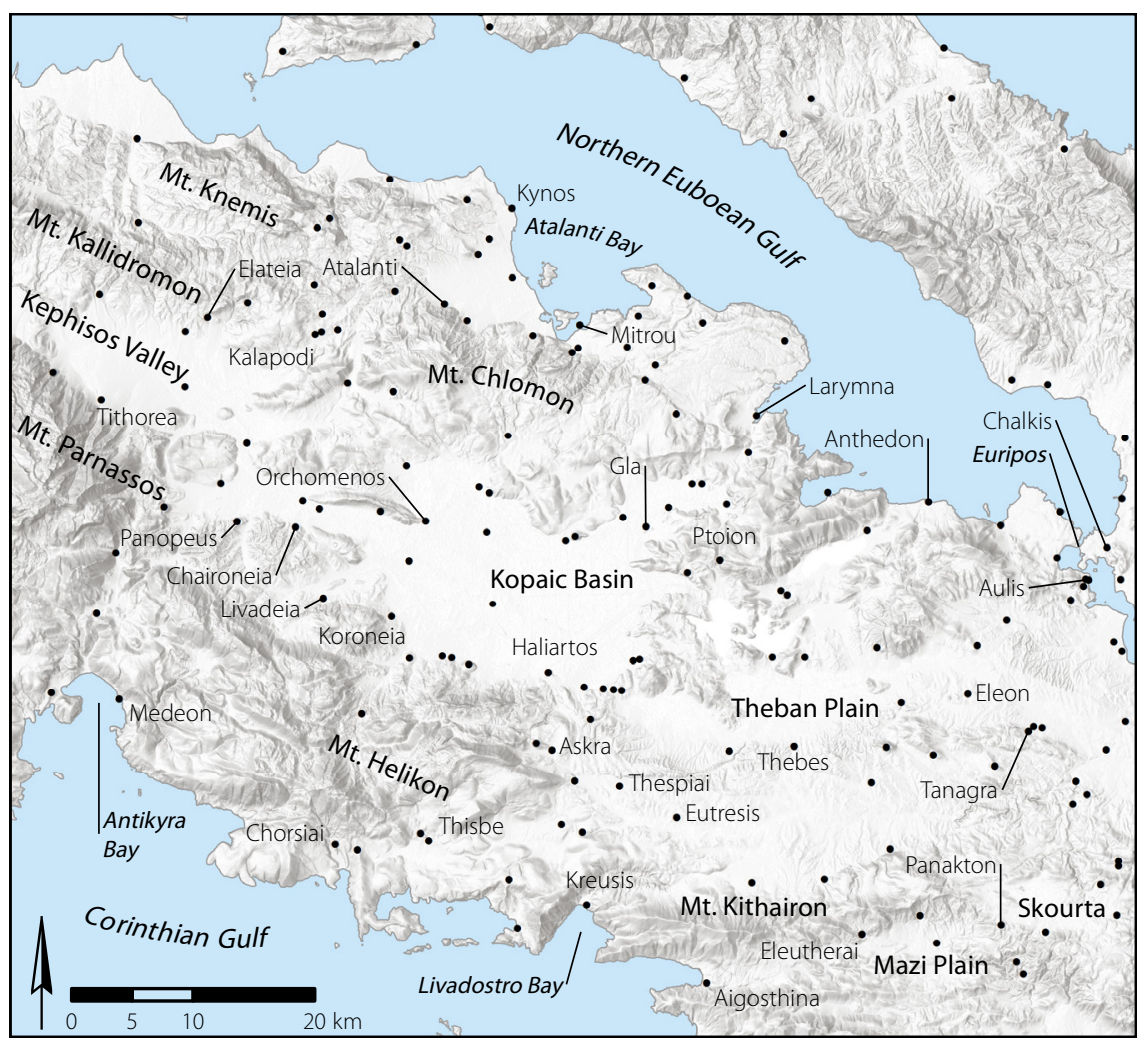

MAP 4. Topography and sites of Boeotia and East Lokris, with major sites and features labeled.

In the northern part of Boeotia, in the domain of Orchomenos, the Kopaic Basin is the major feature, the nature of which changed drastically in the span of time dealt with in this study. While this is naturally an area that fluctuates between lacustrine and marshy conditions, it was drained in the Mycenaean Palatial period (LH III A2/B1, ca. $1300 \mathrm{BCE}$ ), reclaiming an area of approximately 300 square kilometers for agricultural purposes through a system of dikes and canals (Knauss, Heinrich, and Kalcyck 1984; Knauss 1987; Iakovidis 2001; Lane et al. 2020). The implications of these massive landscape interventions are several but the interventions themselves were short lived, disappearing with the end of the Palatial era (see further in chapter 3 ). Like Thebes, Orchomenos is approximately equidistant from the Euboean and Corinthian Gulfs. To reach the Corinthian Gulf, the most direct route is to go either west toward Delphi, or south to Chorsiai. For the Euboean Gulf, one can either (1) follow the north side of the Kopaic Basin to Gla and then Larymna, (2) head east-northeast toward the eastern end of the plain of Atalanti, or (3) go north, past Kalapodi, to enter the plain of Atalanti on its western edge and arrive at the gulf from there. The final major route from Orchomenos leads 
northwest, following the course of the Kephisos River, along the southern edge of Mount Kallidromon, through Phokis and beyond. A western track through Phokis takes one to Delphi via Livadeia and eventually to the harbor at Itea, which is on the Corinthian Gulf.

Until now, Boeotia has been the subject of more rigorous study than other areas in central Greece. A long history of regional research has involved topographic study (Fossey 1988), as well as a long line of intensive survey projects, including the longest running regional survey in Greece, the Boeotia Project, which has existed in several iterations since the 1970s (Bintliff and Snodgrass 1985; Bintliff, Howard, and Snodgrass 2007; Bintliff et al. 2017). Other modern surveys include the Eastern Boeotia Archaeological Project (Burke, Burns, and Lupack 2009; Aravantinos et al. 2016a) and several projects along the southern border with Attica on the Skourta Plain, the Mazi Plain, and in the vicinity of Oropos (Munn and Munn 1989, 1990; Cosmopoulos 2001; Fachard, Knodell, and Banou 2015; Knodell, Fachard, and Papangeli 2016, 2017; Papangeli, Fachard, and Knodell 2018). In addition to the studies of settlement, there is a long tradition of research on land routes and archaeological evidence for roads in Boeotia (Heurtly 1925; Fossey 1988, 157-63; Hope Simpson and Hagel 2006, 163-64). A recent synthetic regional study (Farinetti 2011) has brought together diachronic evidence of settlement from the entire region and mapped the archaeologically testified or topographically likely routes that traverse Boeotia through a combination of GIS analysis and the evaluation of archaeological data across the region as a whole.

\section{Phokis}

Phokis is defined by two mountain ranges (map 5). The Kallidromon range forms the northeast border of Phokis and eventually runs into Boeotia. The second is the southern end of the Pindos range. Mount Parnassos dominates the landscape of the region and separates it into two parts. The northern part, which runs northwest-southeast, is defined by the Kephisos valley, with the river flowing into Boeotia near Chaironeia. The valley provided fertile agricultural land for several ancient polities and was one of the two principal land routes that connected Phokis and Boeotia to East Lokris and, beyond that, to Malis and Thessaly. The northern boundaries of the region therefore occupy a crucial dividing point between northern and southern Greece, most notably at the celebrated pass at Thermopylai. The southern part of the region is characterized by mountainous terrain that gives way abruptly to the Corinthian Gulf. From the bay of Itea to Amphissa, however, there is a well-watered plain of long-term significance. The bay of Itea, the port of Delphi, marked an important outlet to the sea on the west side of the region, with Antikyra Bay and the important site of Medeon on the east.

Historically, Phokis has played a vital role in the sociopolitical dynamics of the study region as a whole, having been linked to the affairs of Boeotia, East Lokris, and beyond (McInerney 1999). In addition to the Kephisos valley, which provided 


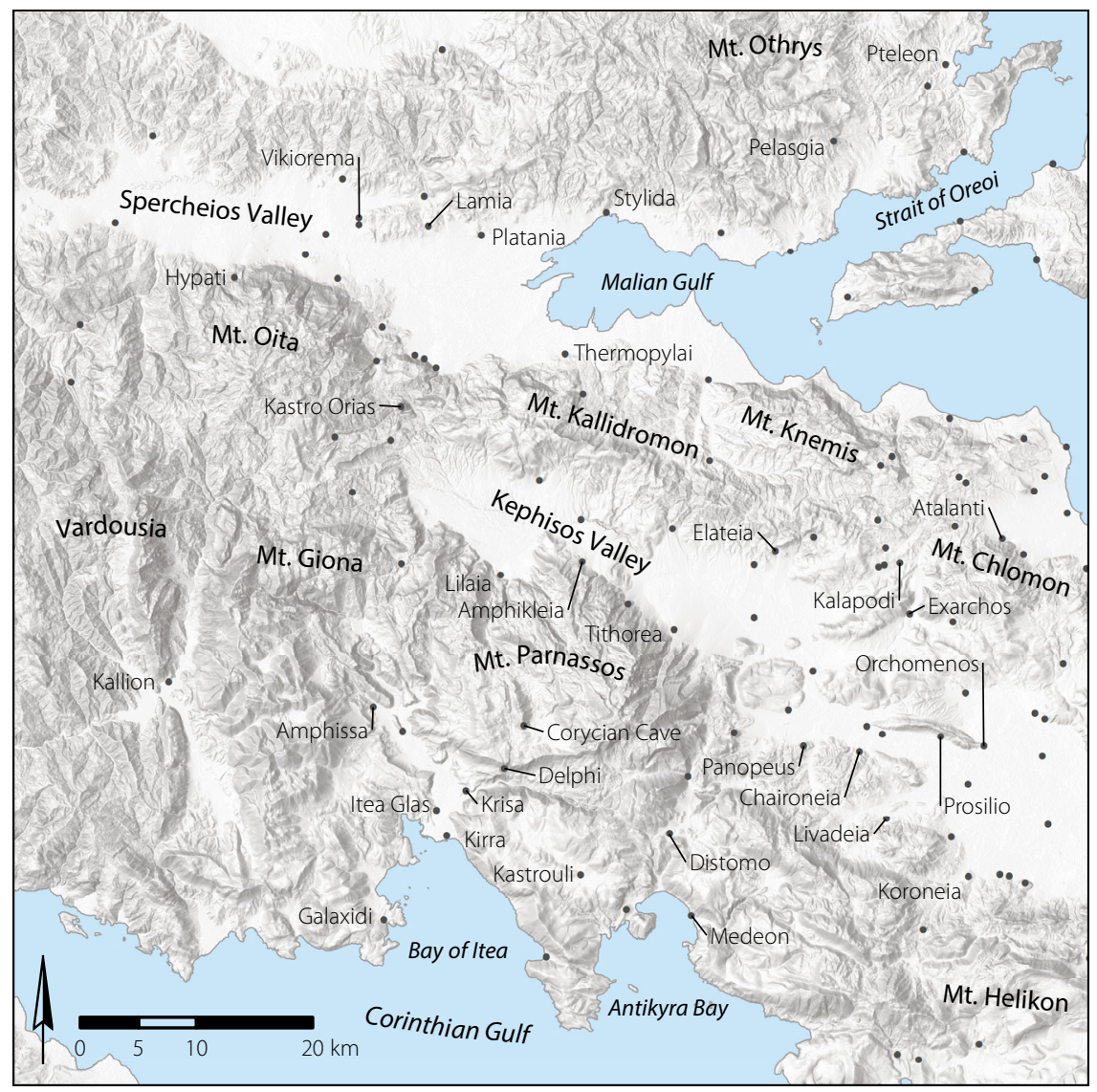

MAP 5. Topography and sites of Phokis and Malis, with major sites and features labeled.

a natural extension north from Boeotia, the two bays of Itea and Antikyra provided outlets to the Corinthian Gulf, opening up to the west. For the periods under study here in particular, these zones were both locations of important Mycenaean coastal sites, and in the Early Iron Age Delphi was already becoming a major interregional sanctuary. On the northeast side of Phokis, Tithorea and Elateia were important settlements in the upper Kephisos valley. Kalapodi was a regional sanctuary of equal (and in some periods greater) significance to Delphi during the Late Bronze Age and Early Iron Age, occupying a confluence of east-west routes between East Lokris and Phokis (and the Euboean and Corinthian Gulfs) and north-south routes between Malis and Boeotia (Felsch 1996, 2007; Niemeier 2016). The town of Exarchos (associated with ancient Hyampolis) is located in a small valley connecting Kalapodi and Orchomenos, providing a further point of linkage between landscapes. 
The centrality of Phokis - both geographically and historically-as a hub for ritual and commercial activity has long made it of interest to topographers and archaeologists (Oldfather 1916; Fossey 1986; Kase et al. 1991; McInerney 1999; Livieratou 2020). Regional survey in the area has been more limited. An extensive survey was carried out along the Great Isthmus Corridor Route; this also included a discussion of connections to the Spercheios River valley to the north (Kase et al. 1991). A variety of excavation work has also been carried out in the bay of Kirra, an outgrowth of the long-standing interests of the French School at Delphi (e.g., Dor et al. 1960; Zurbach et al. 2012-13). The bay of Antikyra, too, has seen important excavation work at Medeon (Vatin 1969; Pelon 1976, 238-39; Livieratou 2012, 2015; Sideris 2014); slightly inland from here, recent excavations at Kastrouli, near Desfina, suggest there is even more to the picture of settlement in this area than had been previously thought (Sideris and Liritzis 2018). In northern Phokis, work at the many significant sites in the upper Kephisos valley has been carried out by the Austrian Archaeological Institute at Athens, particularly at Elateia (e.g., DegerJalkotzy 2009) and in various other places by the Greek Archaeological Service (e.g., Dakoronia 2009).

\section{East Lokris}

East Lokris is a relatively narrow strip of land between the Kallidromon mountain range and the Euboean Gulf (see map 4). It is traditionally divided into two parts: Epiknemidian Lokris (the landscape of which is dominated by Mount Knemis) and Opountian Lokris (after the ancient city of Opous) (Dakoronia 1991). Both are located on the shores of the northwestern part of the Euboean Gulf and are often referred to together as East Lokris, a region geographically distinct from Ozalian Lokris, which is located on the Corinthian Gulf, on the opposite side of Phokis. The most central feature for settlement in East Lokris is the bay of Atalanti and the attached agricultural plain. Settlement evidence clusters in a triangle between the important sites of Atalanti (inland), Kynos (on the northwest side of the bay), and Mitrou (on the southeast side).

Topography has long been a concern in East Lokris (Fossey 1990; Pascual and Papakonstantinou 2013). In the late twentieth century, an archaeological survey of the region grew out of work at ancient Halai, with a more specific focus at Mitrou (Coleman et al. 1992; Kramer-Hajos and O’Niel 2008). This work was followed by long-term research excavations by the American School of Classical Studies at Mitrou, a site of particular importance for the transition from the Bronze Age to the Iron Age (van de Moortel and Zahou 2011, 2012; see also Tsokas et al. 2012; Vitale 2011; Lis 2017). The vast majority of the archaeological work in the wider area has been carried out in the form of research and rescue excavations by the Greek Archaeological Service, especially under the direction of Dakoronia (Dakoronia 2009; Papakonstantinou, Kritzas, and Touratsoglou 2018). For the region as a whole, Kramer-Hajos $(2008,18-34)$ provides a synthesis of evidence from the 
Mycenaean period, as well as information about the geology, topography, climate, vegetation, and agriculture of the area (see also Livieratou 2020). Access to the Euboean Gulf is mediated through paths that work their way around and through the Kallidromon range, Mount Knemis, and Mount Chlomon. As is the case with Phokis, Kalapodi is a location of particular significance on the pass that connects the upper Kephisos valley running through Phokis and Boeotia to Lokris. This is the principal land route into Lokris from the south and west, whereas from the south or east one can skirt the slopes of Mount Chlomon to enter the plain of Atalanti on the east side, near Mitrou and Halai. To move northwest from Lokris, the easiest route is to follow the seaside edge of Mount Knemis up the coast to the Malian Gulf, passing Thermopylai to enter the coastal plain of the Malian Gulf. A recent, multidisciplinary study of the history and topography of Epiknemidian Lokris highlights the particular combination of mountains and sea that characterizes this microregion, as well as its clear relationships with the surrounding landscapes (Pascual 2009; Pascual and Papakonstantinou 2013).

\section{Malis}

Malis forms the heart of the modern prefecture of Phthiotis, which extends from southern Magnesia and the regional unit of Larissa in the north to Phokis and Boeotia in the south, and from the Malian Gulf in the east to Evritania in the west (see map 5). Phthiotis thus includes East Lokris and the upper Kephisos valley. The ancient region of Malis is the zone surrounding the Malian Gulf and Spercheios valley. The region demarcated in this study also includes (depending on fuzzy historical boundaries) areas associated with the names Doris, Ainianaia, Oitaia, Dolopia, and Phthia (see Decourt, Nielsen, and Helly 2004). For our purposes, the Spercheios valley is the central feature, and the region is bordered by Phokis and East Lokris to the south and Thessaly to the north. The natural features forming these boundaries are Mounts Oita and Kallidromon in the south and the Othrys range in the north.

The most comprehensive regional study of this area remains Béquignon's (1937) work on the Spercheios valley. Since then, survey work has been rather limited, although the Phokis-Doris expedition, focused on the Great Isthmus Corridor Route (Kase et al. 1991), included parts of this zone, most notably a summary of the Bronze Age and Early Iron Age evidence for settlement in the Spercheios valley (Dakoronia 1991). More recently, intensive survey work has been carried out in the western end of the valley by the Makrakomi Archaeological Landscapes Project (Papakonstantinou et al. 2013). The vast majority of our archaeological knowledge of the area comes from the numerous rescue excavations carried out by the Greek Archaeological Service (see, e.g., Dakoronia 1994, 1999; Karantzali 2013; Papakonstantinou 2009, 2015; Papakonstantinou et al. 2016).

The landscape of Malis and areas to the north are delimited quite starkly from regions farther south. The sheer northern face of Mount Oita forms an imposing 


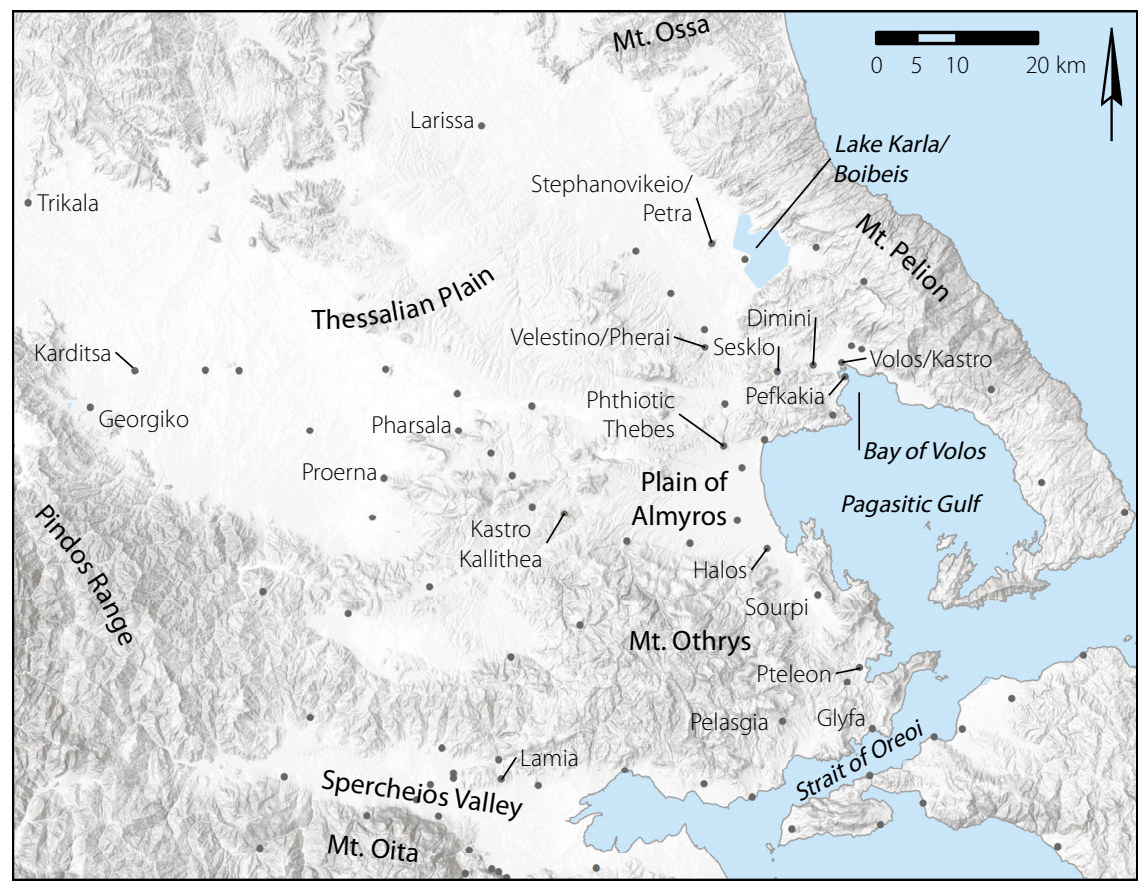

MAP 6. Topography and sites of Thessaly, with major sites and features labeled.

barrier when viewed from the Spercheios valley, and the difficulties of moving south from there by land are well documented in Herodotus's account of the Persian invasion of Xerxes and the strategic significance of Thermopylai, on the east side, and of the difficult-to-find Anopaia pass (see, e.g., Herodotus 7.215-17; Pritchett 1982; Rapp 2013; Rop 2019). Such narrow passes, of which there are few, were therefore of paramount importance and have had long-term influence in the history of settlement for the region. To the north, crossing Mount Othrys, there are more options to arrive in southern Thessaly and the historical region of Phthia.

\section{Thessaly}

The southern part of Thessaly (south of Larissa and southeast of Trikala) is the northern limit of the study area (map 6). North of the mountain passes connecting Thessaly to Malis, the expansive Thessalian Plain offers ample opportunity for agriculture and movement (Decourt 1990; Helly 1999). For access from the south, Mount Othrys is a major obstacle for travelers, generally forcing them west to the passes noted above to enter Thessaly near Proerna and Pharsala, or along the coast of the Euboean Gulf, between the mountain and the strait of Oreoi, to enter the plain of Almyros along the west side of the Pagasetic Gulf. The bay of Volos, at the northern end of the Pagasetic Gulf, provides the main point of connection 
to the Aegean. The territory to the east is dominated by Mount Peleon, as is the area to the north, separating the rich interior plain from the coast until one reaches the southern edges of the Thermaic Gulf. This means that-north of Lamia-the Pagasetic Gulf is the most favorable outlet to the Aegean until one reaches the northwest corner of the Aegean.

The major land route to northern Greece runs from Volos toward Larissa, with several offshoots into western Greece along the way, especially via Pharsala and Karditsa. People traveling south would have most likely entered the Euboean Gulf from the Pagasetic Gulf, passing along the length of this sea route and likely needing to stop along the way. The importance of Thessaly as a connection to the north of Greece, both by land and by sea, is paramount throughout the period of study.

The classic work on the prehistory of Thessaly is Wace and Thompson (1912). The Neolithic period has historically received pride of place, especially the Neolithic type sites of Dimini and Sesklo (see, e.g., Tsountas 1908; Theocharis 1973; Gallis 1992; Andreou, Fotiadis, and Kotsakis 2001). For historical times, scholarship highlights the complicated political geography of Thessaly and the surrounding areas (Morgan 2003; Decourt, Nielsen, and Helly 2004). Much recent work has focused on the Mycenaean period, most notably at the major centers of Dimini, Kastro Volos, and Pefkakia (Batziou-Efstathiou 2015; Skafida et al. 2016; Adrimi-Sismani 2017, 2018). Regional survey work has been limited to the catalog-type approaches of the gazetteers (Feuer 1983; Gallis 1992), and occasional extensive surveys (Decourt 1990). The only published intensive survey work in the region has focused on the Almyros and Sourpi Plains (Reinders 2004; Stissi et al. 2015), although the new Central Achaia Phthiotis Survey, building on a long-term project at Kastro Kallithea, has much potential (Haagsma 2019). Perhaps the most significant trend in the archaeology of Thessaly is recent conferences that have published a wealth of new information about a variety of periods and sites (Mazarakis Ainian 2006, 2009, 2012C, 2016, 2020). Synthetic studies of the region in the Late Bronze Age (AdrimiSismani 2007; Pantou 2010; Feuer 2011, 2016b) and the Early Iron Age (Georganas 2003, 2011; Karouzou 2017, 2020) provide a more comprehensive picture.

\section{Euboea}

Euboea has a varied natural environment, characterized by mountains and valleys, small agricultural plains, and wooded highlands. Routes of communication are largely determined by the contours of the landscape and the necessity to find favorable passes through often mountainous terrain (map 7). In general, however, this terrain is much more difficult to cross than that of Boeotia or Attica, which has in part led to historical territorial divisions between different parts of the island, also observed by archaeologists, historians, and geographers (Sackett et al. 1966; Fachard 2012; Tankosić, Mavridis, and Kosma 2017; see above, pp. 34-37, n. 1, for more on the history of research for the island). 


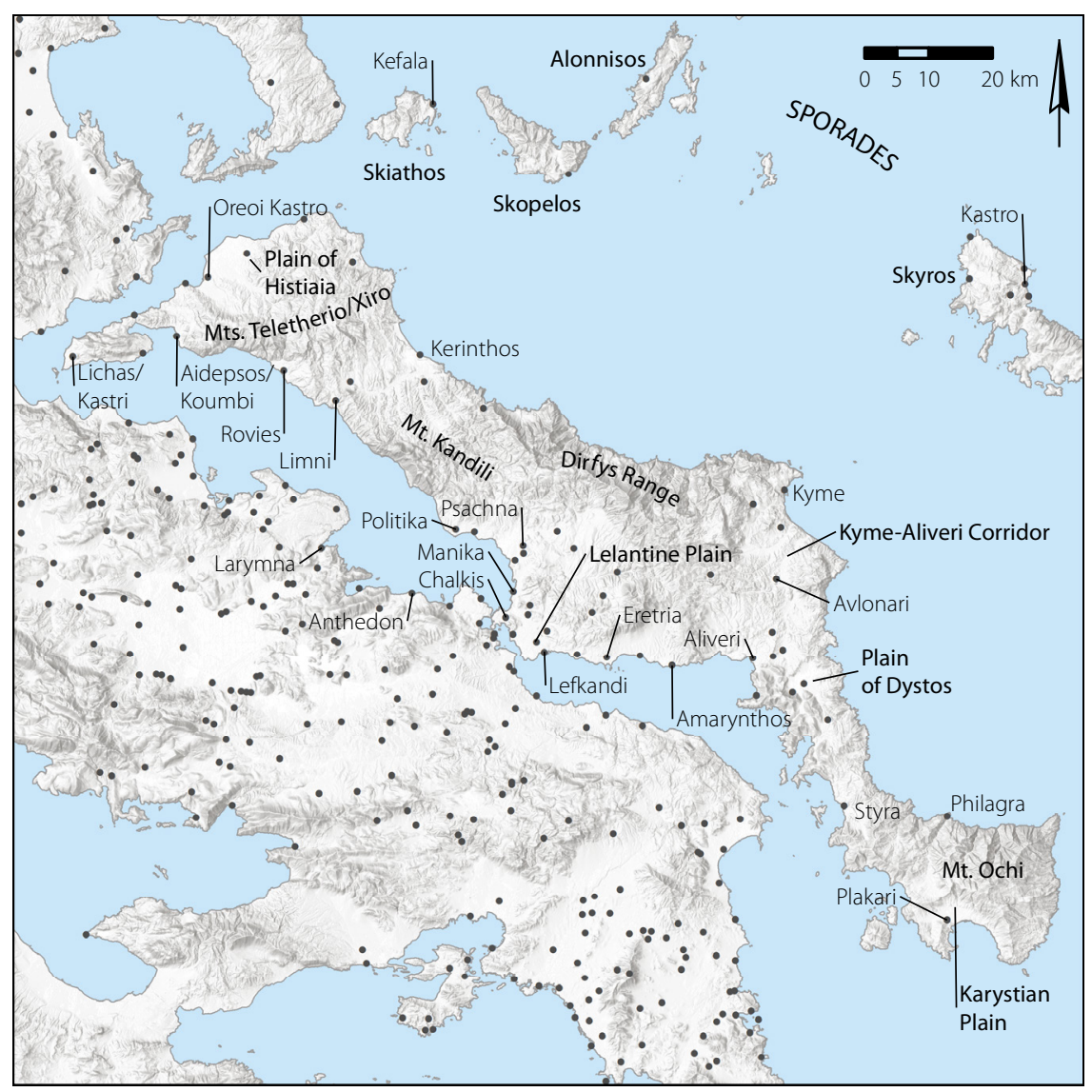

MAP 7. Topography and sites of Euboea and the Sporades, with major sites and features labeled.

A major feature of Euboea is the strait of the Euripos, where the Euboean Gulf narrows to a width of ca. 50 meters. This is also the location of Chalkis, the principal settlement of Euboea for much of its history. In later times this channel has been spanned by a variety of bridges. In the periods covered here, however, the famed unpredictability of the water currents would have made smaller vessels dependent on the tide to cross, and so would have forced them to wait in the northern or southern harbors (or at least their vicinity) until the appropriate time, further highlighting the geographical and historical importance of Chalkis (Bury 1887; Bakhuizen 1976, 1985; Kontogiannis 2012; Kosma 2015; Kalamara et al. 2015; Mastrogiannopoulou and Sampson 2017). This situation also would have increased the appeal of nearby harbors, for example at Lefkandi, Eretria, and Aulis to the south, and at Larymna and Anthedon (on the Boeotian coast) to the north. 
Throughout the island, mountainous landscapes necessitate taking paths that are not direct, especially along the limited land routes connecting the disparate north, central, and southern parts. These geographic limitations are also a feature of the paths between the Aegean coasts and the Euboean Gulf, with a few notable exceptions. The corridor between Kyme and Aliveri, for example, contains some of the most important agricultural land on the island, with valleys branching off this main route linking the Euboean Gulf with the Aegean coast. Large coastal plains are present in only a few locations: at Histiaia in the north; at Psachna and between Chalkis and Eretria in the center of the island; and around Dystos and Karystos in the south.

The highly fragmented landscape of Euboea signals the importance of sea travel, especially along the Euboean Gulf. The use of land routes would certainly have been widespread, but these should be seen as small-scale and occurring only rarely over great distances. The implications of this are important for the Euboean Gulf as a major maritime corridor, since (1) contacts between polities in distant parts of the island are likely to have been primarily maritime in nature; (2) longdistance contacts coming through ports give such locations prominence in landbased networks as well; and (3) the gulf coast of the island is more connected from both terrestrial and maritime perspectives than is the Aegean coast, which has prominent sites only in the areas of Kyme and Kerinthos, both points of connection to the Sporades, which also have significant material cultural affinities with Euboea, especially in the Early Iron Age (Lemos and Hatcher 1986; Mazarakis Ainian 2012b).

\section{Attica}

Home to Athens and its well-documented system of demes, Attica is one of the most important parts of the Greek world for understanding the organization of ancient landscapes and territories (Traill 1975; Whitehead 1986; Fachard 2016). The Attic peninsula is delimited in the north by the Kithairon-Parnes range, which separates it from Boeotia, and on the west by the isthmus separating it from the Peloponnese (or, more specifically, Mount Pateras, which separates western Attica from the Megarid) (map 8). Attica itself can be divided into three parts: western Attica, extending from the Megarid to Mount Aigaleo and including the bay of Eleusis; the basin of Athens, between Mounts Aigaleo and Hymettos; and eastern Attica, which is bounded on the west by Mount Hymettos and on the east by the Euboean Gulf.

Passage through Attica is fairly straightforward and the landscape is generally less challenging than other places. On a regional scale, routes mainly involve negotiating Mounts Hymettos, Pentele, and Parnes, as well as the smaller mountains in southern Attica (Vanderpool 1978; Lohmann 2002; Korres 2010; Fachard and Pirisino 2015; Fachard and Knodell 2020). The importance of eastern Attica for the period in question (and later periods as well) is paramount. The rich silver and 


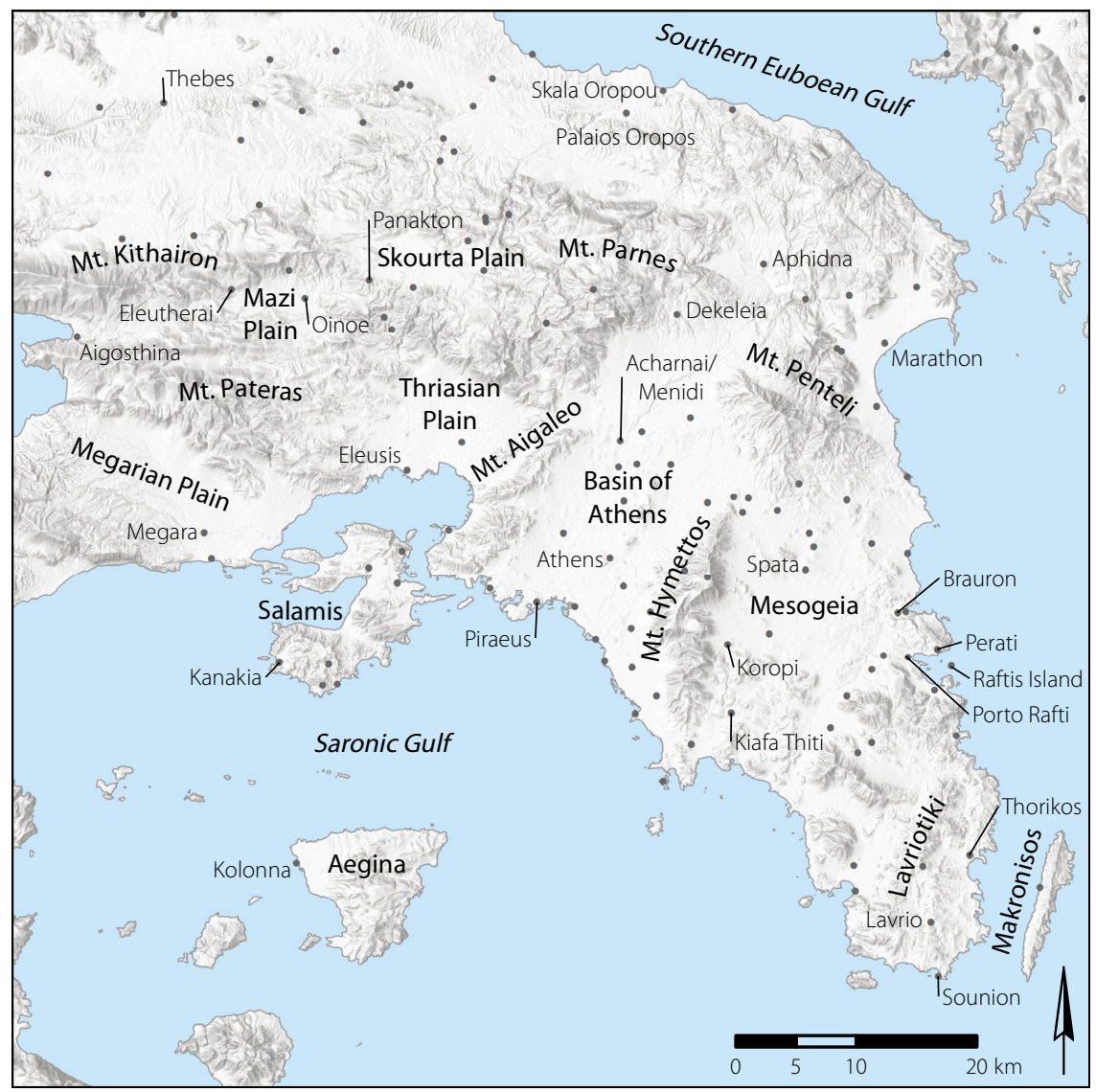

MAP 8. Topography and sites of Attica and the Saronic Gulf, with major sites and features labeled.

copper deposits of the Lavriotiki were major commodities, and the relative ease with which they could be accessed by sea was also significant (Lohmann 2005; Domergue 2008; Papadimitriou 2017; Kayafa 2020).

Finally, the routes coming into and out of Attica are more clearly circumscribed than movement is within Attica itself. Mounts Parnes and Kithairon present fairly substantial borderlands, forcing people traveling overland to take either a western or an eastern course. The former leads toward Boeotia and the Corinthian Gulf, which passes through the Mazi Plain and later border settlements and forts at Panakton, Eleutherai, and Oinoe (Fachard and Knodell 2020). The latter leads in the direction of the Euboean Gulf, skirting the east side of Parnes to enter Boeotia near Oropos, territory that was hotly contested in historical times (Cosmopoulos 2001).

Unfortunately, systematic survey on a regional scale is simply not possible in the vast majority of the region, dominated as it is by the sprawl of the modern 
capital. Nevertheless, extensive archaeological work has been carried out over centuries by topographers, explorers, and (especially) the Greek Archaeological Service (see, e.g., Stuart and Revett 1762-1816; Leake 1821; Traill 1975; Osborne 1985; Goette 2001; Lohmann and Mattern 2010). Now is an especially important time for the study of early Attica, marked by the recent publication of several important volumes on the prehistory and early history of Athens and Attica (Privitera 2013; Papadopoulos and Smithson 2017; Doronzio 2018; Dimitriadou 2019; Graml, Doronzio, and Capozzoli 2019; Papadimitriou et al. 2020). New survey projects at Thorikos, Porto Rafti, and Aphidna also promise to shed much new light on the regional dynamics of eastern Attica in the Late Bronze Age (see table 3).

Each of the regions described above varies internally in considerable ways, but they nevertheless have certain coherences that tie them together, not least land and sea routes. Overland travel was certainly the norm for most people, most of the time. Sea travel should be seen as less common in everyday life, as suggested by Hesiod, who traveled by boat only once and warns against the dangers of the sea (Works and Days 641-77). Nevertheless, the sea was a defining feature of early Greek society. There is therefore a need for models that account for connectivity both by land and by sea.

\section{NETWORK MODELS IN GEOGRAPHICAL SPACE}

The regional data sources discussed above establish a baseline pattern of settlement across the entire study area for each period in question. The next step involves an attempt to understand how landscapes of settlement connect and cohere, and how these things change over time. The analysis of routes in the landscape and connections between places is essential to understanding the organization of political landscapes. There is a nearly direct correlation between investment in communication infrastructure-including roads, paths, way stations, and guard postsand level of social complexity. For example, in a comparative study of cases from North America, Central America, South America, and northern Mesopotamia, Earle (2010) has shown that only highly complex chiefdoms and states are typically engaged in road-building activities. This model generally fits our knowledge of early Greek infrastructure, which is rather limited, dating only to the Mycenaean and Classical periods, with a large gap in between (Kase 1972; Pritchett 1980; Goette 2002; Jansen 2002; Hope Simpson and Hagel 2006; Fachard and Pirisino 2015; Fachard and Knodell 2020). Direct archaeological evidence for movement in early Greece is therefore fleeting. It is limited to roads and road remains dated to certain times when centralized polities were investing in regional infrastructure (the Mycenaean Palatial period) - and even then the material evidence is by no means ubiquitous. In spite of this lack of evidence for infrastructure, we know that people were on the move almost constantly. Routes of potential movement or paths 
of habituated movement are other ways of conceptualizing such mobility (Earle 2010). Using the landscape to generate potential routes based on GIS modeling, considering also later maps and travelers' accounts, is one important way forward.

Network modeling provides a powerful means of approaching connectivity, and in multiple ways. As noted in chapter 1, network analysis in archaeology often aims to document or analyze interaction through perceived similarities in ceramic styles or production and exchange practices (see, e.g., Knappett 2011; Blake 2014). My aim is rather to model archaeologically ephemeral interactions on local and regional levels. Nearest-neighbor analysis is employed to provide a baseline for interaction, based on the assumption that any given site will interact with at least three of its nearest neighbors. This assumption stems from the fact that communities need to interact with one another in order to diversify agricultural and craft production, to participate in intercommunal social storage practices, and to make suitable marriages between what are generally small agricultural communities (Halstead 1989; Borck et al. 2015). Such issues are of fundamental importance in the Mediterranean microecologies of central Greece, with their varied and seasonally unstable resource bases.

The type of nearest-neighbor model employed here is similar to the proximal point analysis used by Broodbank (2000, 180-86) for the Early Bronze Age Cyclades, though it differs in that it includes only known sites, involves a larger area, and puts equal emphasis on both land- and sea-based interaction. The model connects each community (see above on the distinction from site) with a minimum of three nearest neighboring communities, establishing a baseline that is uniform throughout the study area. ${ }^{5}$ This is not to suggest that these were the only interactions that took place, or even that these were the most important interactions for a particular community, but this model serves (1) to provide an architecture of interaction that is simply not possible to know in its entirety from material evidence alone, and (2) to show how likely interactions between settlements change over time, in the face of shifting settlement patterns. Rendering such connections graphically for each period in the chapters that follow allows us to see also how local or regional groupings emerge.

In addition to generating conceptual models of interaction between neighboring communities, I also map likely routes through which individuals and groups would have moved to make such connections. While general routes traversing and connecting the regions of central Greece are described above, smaller-scale paths between specific places also would have been important to early Greek communities. Least-cost paths are therefore used to create a connectivity model of sites in

5. Three is a conventional number of connections drawn in Proximal Point Analyses (see Broodbank 2000: 180-81; see also Terrell 1977). Models using four or five would not yield substantially different results, since the objective is to model relative connectivity rather than to suggest an absolute pattern. For a variety of models derived from a much larger dataset with different numbers of connections, see Brughmans and Peeples 2020. 
the landscape for each of the relevant periods. ${ }^{6}$ This connectivity model works in two ways. In the first place, it finds a single optimal route through which all sites in the model can be connected. In the second, it articulates the optimal paths through the landscape to connect each site to its nearest neighbors. What emerges is a two-tier model of main axes (displayed in the maps that follow as bold lines) and other routes (displayed as lighter lines) for each of the four periods discussed in the following chapters (see maps 10, 15, 19, 25). These least-cost paths therefore link all sites as activity zones represented in the archaeological record, even if they do not represent an independent community.

Research in Attica has demonstrated the particular utility of least-cost path models, especially because they tend to map well on to (1) material remains of road construction dated to the Mycenaean and Classical periods as well as (2) several other sites and findspots (Fachard and Pirisino 2015; Fachard and Knodell 2020). The application across several regions allows for the identification of much larger trends and regional specificity. Taken together, then, nearest-neighbor networks and connectivity models provide a layered approach to modeling networks of interaction across multiple geographical scales.

\section{TERRITORIAL MODELS IN DYNAMIC LANDSCAPES}

The contemporary world is comprised of states with relatively static borders that delimit contiguous territories. Political boundaries are demarcated by lines on maps, while strict national laws and international agreements denote what can and cannot be done within and between these zones. Political space would have been conceived quite differently in early Greece, along with much of the rest of the premodern world (see also Cherry 2010). Boundaries existed, to be sure, and we know from later historical sources that territories were present and contested, won and lost; but these must have been more fluid and relative than we tend to render them on maps. It may be more useful to think of territories as agglomerations of sites, networks, and routes-conceptions of territory and distance based on links that actively create relationships between places rather than boundaries that contain such places. In this way we might see territories as clusters of relationships whose character can sometimes be deduced through the material or documentary record but must also depend on a regional proxemics of frequented places and

6. Such methods are now well established in archaeological research as ways of modeling likely paths of interaction in the landscape (see, e.g., Howey 2007; McCoy and Ladefoged 2009; Gillings, Hacigüzeller, and Lock 2020). The least-cost paths used in this study were generated using ESRI ArcGIS software to create a cost surface that models the relative effort of traversing the landscape. This model was based on a combination of slope, derived from a 30-meter resolution ASTER Digital Elevation Model and a study of the physiological energy cost of humans walking uphill (Minetti et al. 2002). Paths of least resistance were then modeled as likely routes by which people would move through the landscape. 
the natural environment. We must also consider that conceptions of territory are necessarily fluid, and that they change over time and even vary within a particular society. For example, a polity's understanding of territory may be fundamentally different from that of an individual farmer or a shepherd. Nevertheless, geographical methods of modeling territory provide an important backdrop to these linkages and can offer suggestions for identifying potential border zones or landscapes of convergence.

The territorial interests of communities and polities vary throughout the periods discussed in this book. Based on the Linear B texts, we can say that Mycenaean palaces were concerned with land; they may also have had notional territorial limits. In early Greece, these polities are the closest we come to territorial states with definable boundaries until we arrive at the historically documented territorial disputes of Archaic Greek poleis. An implicit interest in boundaries is more difficult to detect in periods in between, where we might turn to more impressionistic analyses of networks, geography, and the amount of land required to sustain a community of a certain size.

I use two specific methods here to examine past interests in exploiting or controlling land: cost-based territorial allocations (for the Palatial period-see chapter 3) and site catchment analysis (where notions of political extent are less clear-see chapter 6). More impressionistic analyses of potential territory based on the distribution of archaeological sites, modeled paths, and the natural environment are also employed throughout this book (and indeed seem our best option in chapters 4 and 5). I describe the methods briefly here, though the models themselves appear in the period-specific chapters in which they are employed.

A long-popular way to render the territory of ancient polities is through the use of Thiessen polygons, which generate borders that are equidistant between each palatial center in the analysis (for Mycenaean palaces, see Renfrew 1975; Bintliff 1977a; Cherry 1977; Galaty and Parkinson 2007). The principle is similar to that of the territorial allocation employed here, except that Thiessen polygons are based on Euclidean distance and all land in the analysis is assigned to a center. This means that the territory of those palaces on the edges will go on indefinitely while those in the center are restricted. Cost allocations do something similar, but they use a cost surface model that integrates topographical information to take into account the relative effort of crossing the landscape (Bevan 2010). More complex models incorporate network centrality and routes (Bevan and Wilson 2013) or historical contingency and diachronic change (Whitelaw 2018; Ek 2020). This study does something similar in the context of Mycenaean palatial territories, although it abandons such centralized territorial modeling in later periods in favor of less prescriptive analysis (when regional centralization and hierarchy cannot be clearly demarcated across the study area).

In a cost-based model of territorial allocation, territory is assigned to sites designated as peer communities, based on whatever peer community in the 
designated set is closest in cost distance terms. The model for cost-based territorial allocation is employed here with a certain restriction-a maximum extent based on the outermost places mentioned in the Linear B tablets from Thebes that clearly fall within the political territory of the center. Significantly, all of the places mentioned in the Thebes tablets with clear territorial relationships to the palace fall neatly within this territorial model, while there is a line of major sites that are not mentioned, which fall just inside territory that would be ascribed to Orchomenos. At first glance, these boundaries are quite similar to those produced by Thiessen polygons, yet there are subtle differences that correspond with what we know about regional networks. The most meaningful distinction is the boundary between Thebes and Orchomenos that puts Larymna, which would have been an important outlet to the Euboean Gulf for Gla and Orchomenos, in Orchomenian territory in a cost-based allocation and in Theban territory in the Thiessen polygons (see further in chapter 3, pp. 73-84, maps 11 and 12).

Site catchment analysis has an equally venerable history in archaeological thought. Site catchments, or resource acquisition zones, can be modeled as the landscapes with which communities would be most familiar and within which members of communities would conduct most of their day-to-day activities, such as agriculture, animal husbandry, and social interactions. Early approaches to modeling site catchments (Vita-Finzi and Higgs 1970) suggested radii of five and 10 kilometers for sedentary and nomadic communities, respectively, based on analogies from animal subsistence territories. Of course, agropastoral societies exhibit a variety of ranges themselves, since shepherds may venture much more widely than farmers. Archaeological applications based on ethnographic analogies of rural villages proposed catchment radii of 2.5 kilometers (Flannery 1976). This settlement radius seems to apply to Boeotia, Attica, and Euboea in the Classical period (Bintliff 1999, 17-18; Fachard 2012, 76; Fachard 2016). While these do not necessarily prescribe political territories, and habitual activities may indeed have been more extended or curtailed, such notional models do provide a baseline that can be compared to the development of human settlement in the landscape over time, especially when these models are considered alongside the distribution of arable land and other resources. Site catchments are used here specifically to examine settlement expansion between the Early Iron Age and the eighth century BCE (see further in chapter 6, pp. 197-8, map 26).

\section{CONCLUSIONS: CONNECTING THE DOTS}

In this chapter I have described the geographical and archaeological contexts for what follows. A vast array of archaeological data relevant to the 700 years treated in this book has been compiled over the last two centuries. Much has been written, too, about the Greek landscape and its relation to the history of human settlement. In outlining these contexts I have aimed also to explain the specific methods and 
models - of settlement patterns, networks, and territories - with which we can fill some of the gaps in our knowledge. Such modeling (implicit or explicit) is the only way to articulate the dots of archaeological sites and blocks of individual regions in a multiregional study of societal development.

Archaeological sites come in a variety of forms, as do the evidence and research from which we are able to evaluate them. Even within sites characterized the same way in terms of type or place in a settlement hierarchy, we may have vastly different levels of knowledge. Returning to the example of Eleon in Boeotia and Psachna in Euboea, we might consider them both second-tier centers in the relative hierarchy of settlement for the Palatial Bronze Age. Eleon is the subject of systematic excavations with the Eastern Boeotia Archaeological Project (Burke et al. 2020), while Psachna is known only from surface remains documented in the middle of the twentieth century (Sackett et al. 1966, 54). Nevertheless, what we can infer about Psachna, based on the fragmentary evidence that does exist, suggests that it was probably similar to Eleon in size and local importance, or at least that it was more similar to Eleon than to Thebes or a minor village or hamlet. While we may not always be able to provide a clear picture of what a site looked like, how many people lived there, or how it was organized in sociopolitical terms, we can make inferences about its relative significance based on our knowledge of sites that appear to be similar. On the level of individual sites and communities, therefore, a certain amount of modeling or projection is required in order to move forward with any analysis that is truly regional or multiregional in scope.

A second level of modeling comes in the form of social and spatial networks, heuristic devices intended to show how local and regional landscapes cohere. Few would disagree that such interactions were necessary or took place, even if the details of specific routes or connections between places are debatable. A dual approach to modeling connections through nearest-neighbor analysis and physical routes by which connections may have been realized reveals much about potential modes of organizing and conceptualizing regional space. As loci of habitation change from period to period, so too did the overall network that knit the landscape together.

Finally, territorial models provide an opportunity to analyze how communities and polities may have conceptualized and partitioned the lands in which they lived. In this case, texts provide an uneven level of detail across the periods under study in this book, making a territorial model for Bronze Age palaces applicable to one period but not necessarily to others. In all periods, however, access to resources - most significantly agricultural resources - is a concern for all communities. Fluctuation in settlement density and distribution therefore need to be taken into consideration across all parts of the study area.

Overall, the combination of archaeological evidence, its qualitative evaluation, and its quantitative and spatial analysis provide the baseline for the archaeological history that follows. While certain individual points in this analysis may be subject 
to critique, model building remains the only way to articulate a detailed study of a large dataset derived from a variety of sources. To return to David Clarke (1973), archaeologists necessarily deal with a sample of a sample of a sample. If our goal is to study past human behavior, we are left only with evidence that takes a material form, that has been preserved, and that has been discovered (and published). The state of the evidence, moreover, varies considerably over a variety of social and spatial scales. Making sense of this mélange across the landscapes of central Greece and in reference to the wider Mediterranean context requires a layered approach to modeling and inference-one that allows us to go from compiling archaeological data in physical space to articulating meaningful societal histories. 